\title{
Problem wykładni art. 114 konstytucji marcowej w świetle orzecznictwa kościelnego w sprawach malżeńskich
}

Konstytucja marcowa zawierała przepisy należące do zakresu prawa wyznaniowego (art. 110-116 i 120), określające przede wszystkim stosunek państwa do wspólnot religijnych. Przepisy te zostały następnie utrzymane w mocy przez konstytucję kwietniową. Podstawowe znaczenie miał art. 113 przyznający wspólnotom prawo zarządu swoimi sprawami, ale jednocześnie podkreślający w ostatnim zdaniu, że żaden związek religijny nie może stawać w sprzeczności z ustawami Państwa. Związki wyznaniowe o dłuższej historii opierały swoją działalność na prawie kościelnym. Prawo to według konstytucji marcowej mogło mieć moc wiążącą, jeżeli nie stało w sprzeczności z polskim porządkiem prawnym (art. 115 konstytucji: „Kościoły mniejszości religijnych i inne prawnie uznane związki religijne rządzą się same własnymi ustawami, których uznania Państwo nie odmówi, o ile nie zawierają postanowień sprzecznych z prawem"). Niestety, w przypadku kościoła rzymskokatolickiego, zagadnienie jego jurysdykcji, a zarazem zakresu obowiązywania prawa kanonicznego, komplikowało się głównie za sprawą niefortunnego sformułowania ustępu drugiego art. 114 („Kościół Rzymsko-Katolicki rządzi się własnymi prawami”). Później uzupełniono tę regulację postanowieniem art. I konkordatu z 1925 r. („Kościół katolicki, bez różnicy obrządków, korzystać będzie w Rzeczypospolitej Polskiej z pełnej wolności. Państwo zapewnia Kościołowi swobodne wykonywanie Jego władzy duchownej i Jego jurysdykcji, jak również swobodną administrację i zarząd Jego sprawami i Jego majątkiem, zgodnie z prawami Boskimi i prawem kanonicznym"). Ponadto art. XXV konkordatu przewidywał uchylenie kolidujących przepisów prawa krajowego.

Tuż po uchwaleniu konstytucji W. Komarnicki postawił względem ustępu drugiego art. 114, zarzut, że został zredagowany zbyt zwięźle i kategorycznie, nie 
dając rozwiązania prawnego możliwych tutaj wypadków ${ }^{1}$. Pozostałe zdania zamieszczone w art. 114 również pozostawiały wiele do życzenia. Określono w nich w dość zagadkowy sposób pozycję katolicyzmu, mianowicie, że wyznanie rzymskokatolickie zajmuje w Polsce naczelne stanowisko wśród równouprawnionych wyznań oraz że szczegóły stosunku do tego wyznania będą ustalone w konkordacie. Oznaczało to przesunięcie kluczowej regulacji do umowy międzynarodowej, bo skoro państwo w art. 114 wyrzekło się - jak zaznaczał Komarnicki - uregulowania swojego stosunku do Kościoła w drodze ustawy, pozostawiając tę kwestię konkordatowi, to ten postanowić musi, w jakiej mierze Państwo udzieli Kościołowi imperium. W tej drodze również musi nastąpić uzgodnienie ustaw kościelnych i państwowych i usunięcie ewentualnych ich kolizji ${ }^{2}$. W tym stanie rzeczy pozostawała do rozstrzygnięcia kwestia pozycji katolicyzmu w międzyczasie. W związku z tym wątpliwości zgłaszali również przedstawiciele nurtu prokatolickiego w polskiej nauce prawa.

W art. 114 - pisał W. Jaworski - widzę ten brak, że nie zostało powiedzianym, jaki ma być stan między chwilą wejścia w życie konstytucji a konkordatem. Należy zawsze pamiętać, że prawo kanoniczne reguluje całe życie katolików, jeżeli więc powiedziało się że państwo uznaje to prawo, to nie wiem jak w czasie, gdy jeszcze nie ma konkordatu sprawa ma być rozstrzygnięta, gdy jest sprzeczność między prawem państwowem, a kanonicznym. Kościół uważa małżeństwo za sakrament, a więc za należące do jego sfery. Konstytucja zaś w art. 114 uznała prawo kanoniczne. Kolizję tę ma właśnie rozstrzygnąć konkordat, ale nim się go zatwierdzi, a konstytucja wejdzie w życie, co się ma dziać3.

Powyższy wywód dotykał sedna sprawy, mianowicie prawa małżeńskiego obowiązującego w Polsce. Chodziło tu zwłaszcza o prawo obowiązujące na terenie byłego zaboru rosyjskiego, gdyż powierzało ono jurysdykcję cywilną w sprawach małżeńskich sądom kościelnym, a w sprawach małżeństw mieszanych wyznaniowo zawierało przepisy regulujące właściwość sądu do rozwiązania względnie unieważnienia małżeństwa. Przepisy te były sprzeczne z prawem kanonicznym. Powstawało zatem pytanie: co obowiązuje w Polsce? Prawo cywilne czy kościelne prawo małżeńskie? W piśmiennictwie wskazywano na ten dylemat. Najbardziej trafne uwagi, bo zresztą wypowiedziane „na gorąco”, tuż po wejściu w życie konstytucji, pochodziły od Komarnickiego. Nie ulega więc wątpliwości, że już współcześni od samego początku dostrzegali problem, który wyłaniał się na tle regulacji art. 114 ust. 2, mianowicie zbyt duże pole do interpretacji. Słusznie później podkreślał Osuchowski, że „nie sformułowanie w omawianym przepisie obowiązku działania kościoła w granicach ustawodawstwa państwowego suge-

\footnotetext{
${ }^{1}$ W. Komarnicki, Polskie Prawo Polityczne, Warszawa 1922, s. 382, przypis.

2 Ibidem, s. 382.

${ }^{3}$ W. Jaworski, Konstytucja z dn. 17 III 1921 r. Prawo polityczne, s. 693.
} 
rowało brak podporządkowania kościoła temu ustawodawstwu i pełną niezależność władz kościelnych od władzy państwowej”" Taką niezależnością kościół rzymskokatolicki był oczywiście zainteresowany i w praktyce osiągnął ten cel tuż po odzyskaniu niepodległości, wykonując jurysdykcję w sprawach małżeńskich w sposób sprzeczny z prawem cywilnym. W konsekwencji poprzez zakres orzecznictwa kościelnego kształtowała się nie tylko pozycja katolicyzmu, ale i wykładnia konstytucji marcowej.

Ustawodawstwo obowiązujące w Polsce po odzyskaniu niepodległości miało różnoraki stosunek do prawa kościelnego. Tylko na części terytorium Polski obowiązywało prawo uznające religijny charakter małżeństwa. Prawo cywilne obowiązujące w byłym zaborze austriackim i rosyjskim, uwzględniając zasady prawa kanonicznego, wykluczało rozwód dla katolików - możliwe było albo stwierdzenie nieważności małżeństwa, albo separacja. W prawie austriackim o niedopuszczalności rozwodu przesądzało wyznanie małżonków w czasie zawarcia małżeństwa. Jeżeli tylko jedno z małżonków w tym czasie było katolikiem, sąd powszechny nie mógł za życia małżonków rozwiązać małżeństwa (§ $111 \mathrm{ABGB}$ ). W byłym zaborze rosyjskim o dopuszczalności rozwodu decydowało natomiast wyznanie małżonków w czasie żądania rozwodu. W przypadku małżeństwa mieszanego wyznaniowo z udziałem katolika obowiązywała $\mathrm{w}$ sprawach rozwodowych zasada właściwości sądu strony pozwanej (wyjątek dotyczył małżeństwa z prawosławnym). W konsekwencji rozwód był możliwy tylko wówczas, jeżeli pozwanym był ten z małżonków, który w czasie żądania rozwodu był wyznania niekatolickiego, bowiem tylko wówczas sąd jego wyznania mógł rozpoznać tę sprawę. Zasada ta obowiązywała na obszarze byłego Królestwa Kongresowego, gdzie obowiązywało prawo małżeńskie z 1836 r. (art. 196 PM), jak i na pozostałym obszarze byłego zaboru rosyjskiego (art. $74^{1} \mathrm{cz} .1 \mathrm{t}$. X zbioru praw ros.). W sprawie unieważnienia małżeństwa prawo cywilne przewidywało właściwość sądu wyznania, którego duchowny najpierw dawał ślub (art. 196 PM). Duchowny ten co do zasady powinien być tego wyznania, do którego należała narzeczona (art. 192 PM), a jedynie wówczas, gdy odmówił on udzielenia ślubu, małżeństwo mogło być zawarte przed duchownym wyznania narzeczonego (art. 194 PM).

Małżeństwo z katolikiem w świetle prawa cywilnego mogło być zatem zawarte wbrew stanowisku duchowieństwa katolickiego, a co za tym idzie pomimo istnienia przeszkód kanonicznych, zwłaszcza imp. mixtae religionis. Prawo małżeńskie z 1836 r. nie przewidywało żadnych ograniczeń dla małżeństw mieszanych w ramach wyznań chrześcijańskich. Wprawdzie w świetle prawa byłego zaboru rosyjskiego małżeństwo cywilne nie mogło powstać bez skutku wyznaniowego,

\footnotetext{
${ }^{4}$ J. Osuchowski, Problemy polskiego konkordatu z 1925 roku, „Państwo i Prawo” 1965, nr 12, s. 843 .
} 
ale w przypadku małżeństwa mieszanego wyznaniowo wystarczało, aby małżeństwo było skuteczne w prawie wyznania tylko jednego z małżonków. W obrocie cywilnoprawnym mogły zatem istnieć małżeństwa z udziałem katolików, które były kanonicznie nieważne. Forma kanoniczna była bowiem wymagana w prawie cywilnym tylko wówczas, gdy narzeczoną była katoliczka. Chodziło tu o formę trydencką (proboszcz i dwóch świadków), którą prawo cywilne Królestwa Kongresowego (art. $48 \mathrm{PM}$ ) przewidywało jako obowiązującą dla katolików. Zawarcie małżeństwa w innej formie, choćby nawet dopuszczalnej w prawie kanonicznym, nie miało skutków w prawie cywilnym.

Forma kanoniczna została rozciągnięta przez Kościół rzymskokatolicki także na małżeństwa mieszane. Regulacja tego zagadnienia znalazła się w Dekrecie o Zaręczynach i Małżeństwie z 1907 r. ${ }^{5}$ Nowe rozwiązania w ramach prawa kanonicznego pogłębiły rozbieżności z prawem cywilnym. Wykluczały bowiem właściwość duchownego akatolickiego w sprawie udzielenia ślubu ${ }^{6}$. Małżeństwa katolików z akatolikami od wejścia w życie 19 IV 1908 r. dekretu Ne temere zawarte bez formy kanonicznej były nieważne ${ }^{7}$. Obowiązujący od 19 V $1918 \mathrm{r}$. Kodeks prawa kanonicznego zasadę tę utrzymał w mocy (kan. 1099). Ponadto, kan. 1060 wprowadził zakaz małżeństw mieszanych, tj. katolika z ochrzczonym przedstawicielem innego zorganizowanego wyznania chrześcijańskiego (heretyckiego bądź schizmatyckiego). Natomiast małżeństwo pomiędzy katolikiem a katolikiem apostatą, który nie wstąpił formalnie do którejkolwiek z sekt heretyckich czy schizmatyckich, nie było traktowane przez Kościół jako małżeństwo mieszane. Wprawdzie małżeństw tego rodzaju dotyczyły również zakazy kościelne, nie miały one jednak charakteru przeszkody tamującej ${ }^{8}$.

${ }^{5}$ Dekret o zaręczynach i matżeństwie z polecenia $i$ władzy Jego Świątobliw. Piusa X papieża Przez św. Kongregacyę Soboru wydany, odbitka z „Przeglądu Katolickiego” za 1907 r. NN 37, 38 i 40 .

${ }^{6}$ Dekret papieski postanowił, że „te tylko małżeństwa są ważne, które są zawierane wobec proboszcza lub Ordynarjusza, albo też kapłana delegowanego przez jednego z nich, oraz wobec dwu przynajmniej świadków...” (art. III). Obowiązek ten według art. XI § 1 dotyczył wszystkich tych zawierających małżeństwo, którzy byli „w kościele katolickim ochrzczeni oraz do niego nawróceni z herezji lub schizmy (chociażby czy to ci, czy to tamci od niego później się oderwali). Dekret $N e$ temere w art. XI § 2 zastrzegał, że prawa te zachowują swą siłę także odnośnie tych katolików, o których wyżej, jeżeli zawierają zaręczyny lub zaślubiny z akatolikami, czy to ochrzczonymi, czy to nie ochrzczonymi, nawet po otrzymaniu dyspensy od przeszkody, pochodzącej z mieszanej religji lub nierówności kultu: chyba, że dla jakiej oddzielnej miejscowości byłyby inaczej od Stolicy świętej postanowione".

${ }^{7}$ Przepisy o postępowaniu w sprawach o nieważność matżeństwa dla Sandomierskiego Sąu Biskupiego, oprac. ks. dr Józef Baron, s. 75.

8 J. Wiślicki, [w:] Matżeństwo w świetle nauki katolickiej. Praca zbiorowa Prof. Uniwersytetu Lubelskiego, Lublin 1928, s. 132-133. 
Wraz z odzyskaniem niepodległości Kościół rzymskokatolicki rozpoczął akcję masowego stwierdzania nieważności małżeństw zawartych przez katolików przed duchownym niekatolickim. Na tym tle doszło do ostrego sporu między konsystorzami ewangelickimi a Sądem Arcybiskupim Warszawskim. Sporem tym musiały zająć się również władze dopiero co odrodzonej Polski. Sytuacja, która się wytworzyła wskutek działalności kurii katolickich, wywoła ogromne wzburzenie wśród społeczności ewangelickiej. Istotnie, wydawane przez Kościół rzymskokatolicki decyzje o stwierdzeniu nieważności małżeństw z tytułu niezachowania formy trydenckiej stawiały osoby wyznania ewangelickiego w niezmiernie trudnej sytuacji. Problem orzeczeń konsystorzy katolickich leżał bowiem nie tylko w sferze kompetencyjnej, lecz także w obszarze regulacji stanu cywilnego. Mianowicie zapadłe z naruszeniem państwowego prawa międzywyznaniowego orzeczenia katolickich sądów duchownych stanowiły kanoniczną podstawę do zawarcia małżeństwa religijnego i sporządzenia kolejnej metryki ślubu, będącej jednocześnie aktem małżeństwa prawno-cywilnego. Orzeczenia konsystorzy katolickich sprzeczne z art. 196 PM wprowadzały więc nie lada zamieszanie. Natomiast okoliczność, że wyroki te pozbawione były skutków prawnych na forum cywilnym, w praktyce pozbawiona była znaczenia. Słusznie bowiem podnoszono w piśmiennictwie, że nieprzestrzeganie tego przepisu prowadzi do zalegalizowanej bigamii z chwilą, kiedy osoby zainteresowane wstępują w nowe związki małżeńskie; bowiem niezależnie od pierwszej metryki ślubu, prawnie nieprzekreślonej, powstaje nowa.

Kościół rzymskokatolicki sprawował orzecznictwo w sprawach małżeńskich w zakresie nieprzewidzianym przez prawo cywilne. Kierował się w swoim postępowaniu nowym prawem kanonicznym. Konsystorze ewangelickie zwróciły się zatem do władz państwowych o interwencję. W dniu 3 IX 1920 r. konsystorz ewangelicko-augsburski w Warszawie wystosował do Ministra Sprawiedliwości pismo, w którym wskazał na praktykę władz Kościoła rzymskokatolickiego, polegającą na stwierdzaniu nieważności małżeństw zawartych przed duchownym ewangelickim zgodnie z art. 192 PM, a więc w przypadku, gdy narzeczoną była ewangeliczka. Podniesiono także, że do rozpoznania ważności związku małżeńskiego właściwym był sąd duchowny tego wyznania, którego jest kapłan dający ślub, czyli w tym wypadku sąd konsystorski ewangelicko-augsburski (art. 196 PM). Natomiast Sąd Arcybiskupi w swoim orzecznictwie opierał się na dekrecie Ne temere z dnia 2 VIII 1907 stanowiącym, że te tylko małżeństwa są ważne, które były zawarte wobec proboszcza albo ordynariusza miejscowego albo kapłana od jednego z nich obu wydelegowanego i że przepis ten obowiązuje nawet tych, którzy zawierają małżeństwo z akatolikami. W dalszej części swojego wystąpienia konsystorz ewangelicko-augsburski odnosił się do postanowienia art. 84 PM, przewidującego stosowanie w katolickich sądach duchownych sądowego postępowania kanonicznego, czyli prawa formalnego. Nie oznaczało to 
bynajmniej rozciągnięcia na Królestwo Kongresowe prawa kanonicznego materialnego, w tym przepisów stanowiących, jakie przyczyny skutkują nieważność małżeństwa ${ }^{9}$. Pogląd ten był ze wszech miar słuszny, bowiem chodziło tu o ocenę ważności małżeństwa mieszanego, którego skuteczność cywilnoprawną określały przepisy państwowego prawa międzywyznaniowego, a nie prawo kanoniczne.

Praktyka unieważnienia małżeństw z naruszeniem prawa państwowego dotykała w takim samym stopniu luteranów, co kalwinów. Stąd podobnej treści pismo do Ministra Wyznań Religijnych i Oświecenia Publicznego wystosował w dniu 2 VI 1921 r. konsystorz ewangelicko-reformowany. Argumentacja konsystorza kalwińskiego wskazywała na brak znaczenia w stosunkach cywilnoprawnych dekretu Ne temere, który wobec tego nie może stanowić podstawy do orzeczenia nieważności małżeństwa, zawartego między osobami wyznania rzymskokatolickiego i ewangelicko-reformowanego jedynie $\mathrm{z}$ tego powodu, że ślubu nie udzielał ksiądz wyznania rzymskokatolickiego. Konsystorz podniósł, że dekret Ne temere z dnia 2 VIII 1907 r. nie został zatwierdzony w drodze ustawodawczej, obowiązującej na obszarze b. zaboru rosyjskiego. Kluczowe okazało się niespełnienie wymagań prawa rosyjskiego, mianowicie:

na zasadzie art. 17 ust. obcych wyznań (Zb. Pr. t. XI cz. 1) żadne bulle, listy i wskazania, w ogóle żadne pochodzące od rządu papieskiego akty nie mogą być wykonywane w Cesarstwie i W.K. Finlandzkim bez Najwyższego zezwolenia J.C. Mości, wyjednywanego przez Ministra Spraw Wewnętrznych po uprzednim przekonaniu, że akty nie zawierają nic sprzeciwiającego się ustawom państwowym, oraz świętym prawom oraz przywilejom Najwyżej Władzy. Tłómacząc ten przepis w zastosowaniu do dzisiejszego położenia politycznego kraju, należy rozumieć, że żadne akty papieskie nie mogą być wykonywane na obszarze R.P. bez uchwały Sejmu Ustawodawczego, wyjednywanej przez Ministra Wyznań po uprzednim przekonaniu się, że akty nie zawierają nic sprzeciwiającego się obowiązującym ustawom państwowym, oraz suwerenności Państwa Polskiego. Nie ulega żadnej wątpliwości, że stosowanie Dekretu Ne temere sprzeciwia się wszystkim niżej przytoczonym ustawom obowiązującym w R.P., i tem samem Jego suwerenności, zaś życiowo stwarza ono sytuacje niedopuszczalne ${ }^{10}$.

Zaprezentowane wyżej stanowisko było aprobowane w piśmiennictwie międzywojennym. Prawo kanoniczne Kościoła rzymskokatolickiego nie tylko nie dało się pogodzić z ustrojem niepodległej Polski, ale nawet poglądami ustawodawcy rosyjskiego, który dał temu wyraz w art. 194 PM. J. Wołowski wskazywał, że ustawodawca ten, kierując się tolerancją, nie chciał dopuścić, ażeby opór niechętnego małżeństwom mieszanym duchowieństwa katolickiego mógł udaremnić jego wolę. Stąd odmowa udzielenia ślubu przez powołanego do tego na podstawie prawa cywilnego duchownego katolickiego nie przesądzała o możliwości zawar-

${ }^{9}$ Archiwum Akt Nowych, Ministerstwo Wyznań Religijnych i Oświecenia Publicznego (AAN, MWRiOP), 2/1345.

${ }^{10}$ AAN, MWRiOP, 10/1345. 
cia małżeństwa w prawie cywilnym. Przepisy prawa kanonicznego nie uwzględniały również reguł rządzących orzecznictwem w sprawach małżeństw mieszanych wyznaniowo.

We wszystkich tych przepisach - stwierdził J. Gwiazdomorski - tkwi daleko idące rozciągnięcie władzy organów Kościoła Katolickiego w stosunku do osób, które do tego Kościoła w swem własnem rozumieniu nie należą i należeć nie chcą. Powyższe przepisy są znowu zupełnie zrozumiałe i jasne, jeżeli się patrzy na nie z punktu widzenia wyłącznie katolickiego. Są jednak nie do przyjęcia z punktu widzenia państwowego. Nie dadzą się one pogodzić z zasadą wolności sumienia i wyznania tak, jak ją pojmują art. 111 i 112 konstytucji11.

Czy byłoby zatem możliwe uznanie prawa kanonicznego w Polsce za wiążące? Konsystorz luterański udzielił trafnej odpowiedzi na to pytanie -

\begin{abstract}
byłoby to w rzeczy samej stwierdzeniem średniowiecznej zasady mocy obowiązującej prawa kanonicznego dla wszystkich osób ochrzczonych, zasady przyjętej przez nowożytną kodyfikację prawa kanonicznego (Cod. Iuris Can., can 12 legibus mere ecclesiasticis non tenentur qui baptismum non receperunt $)^{12}$.
\end{abstract}

Niestety szerząca się w stosunkach rodzinnych anarchia w następstwie oczywistej niekompetencji Kościoła rzymskokatolickiego w sprawach ważności związków w jego obliczu niezawartych zyskała pełną aprobatę Ministerstwa Sprawiedliwości. Minister Sobolewski w piśmie z dnia 19 VII 1921 r., a więc tuż po wejściu w życie konstytucji marcowej, komunikował Prezesowi Rady Ministrów, że stanowisko Konsystorza ewangelicko-augsburskiego oparte jest na błędnej interpretacji prawa cywilnego. Znamienne było zwłaszcza stwierdzenie, że wprawdzie w świetle przepisów cywilnych ślubu może udzielić duchowny ewangelicki zarówno, gdy narzeczona jest tego wyznania (art. 192 PM), jak i wtedy, gdy jest katoliczką, a duchowny jej wyznania odmówił udzielenia ślubu (art. 194 $\mathrm{PM}$ ), ,ale przepisy te nie przegradzają i nie mogłyby przegradzać drogi kościołowi katolickiemu rządzić się prawem kanonicznem, gdy sprawa o sąd jego potem się oprze"13.

Widzimy, więc że zdaniem resortu sprawiedliwości katolicki sąd kościelny nie był związany przepisami państwowego prawa międzywyznaniowego, które określały przesłanki skuteczności cywilnoprawnej małżeństwa wyznaniowego. „Czyżby w rzeczy samej - pisał Jakób Glass - małżeństwo w ten sposób legalnie pod powagą Prawa o Małżeństwie zawarte, mogło ulegać rozwiązaniu, jako niezgodne z przepisami prawa kanonicznego? Na czem się opiera tego ro-

${ }^{11}$ J. Gwiazdomorski, Trudności kodyfikacji osobowego prawa matżeńskiego, „Czasopismo prawnicze i ekonomiczne" 1935, nr 1-12, s. 181.

${ }^{12}$ AAN, MWRiOP, 64/1345.

13 AAN, MWRiOP, 34 i nast./1345. 
dzaju ingerencja prawa kanonicznego do przepisów ustawy, legalnie wydanej i ogłoszonej?" 14 Na te pytania Ministerstwo Sprawiedliwości udzielało następującej odpowiedzi:

Wprawdzie powołując się na art. 84 Pr. o Małż., Konsystorz EA upoważnia kościół katolicki do stosowania tylko postępowania kanonicznego, lecz nie prawa materjalnego kanonicznego. Ale jest to pogląd niedopuszczalny; nie tylko z art. 2, 3, 73 Prawa o Małż., ale i z samego pojęcia „kanonicznego” tj. „kościelnego” prawa wynika, że swojem prawem kościół się rządzić musi, a zatem i dekretem Ne temere $\mathrm{z}$ dnia 2 VIII $1907 \mathrm{r}^{15}$

Stanowisko to, odnoszące się przecież do spraw międzywyznaniowych, oznaczało w istocie uznanie prawa kanonicznego za część systemu prawa państwowego. Natomiast art. 84 PM nie rozciągał prawa kanonicznego na wszystkie przypadki; postępowanie kanoniczne znajdowało zastosowanie tylko wówczas, gdy katolicki sąd kościelny był w myśl art. 196 PM właściwy w sprawie małżeńskiej. W konsekwencji z powyższego poglądu wynika również, że Ministerstwo Sprawiedliwości uznało, że przepisy prawa międzywyznaniowego (m.in. art. 192, 194, 196 PM), pozostające w oczywistej sprzeczności z zasadą rządzenia się przez Kościół rzymskokatolicki własnym prawami, zostały uchylone przez art. 114 konstytucji.

Stanowisko to pociągało za sobą skutki, które w żaden sposób nie dadzą się pogodzić z zasadą nadrzędności prawa państwowego. Uznanie, że dekret $\mathrm{Ne}$ temere wpływa na obowiązujące w Polsce prawo cywilne w praktyce oznaczało, że wyroki kościelne wywierają co do zasady skutki cywilne. Trudno właściwie przecenić, jak daleko idące skutki miały tezy lansowane przez Ministerstwo Sprawiedliwości. Należy mieć bowiem na uwadze, że poglądy tego rodzaju dotknęłyby wszystkich małżeństw w Polsce. Także tych, które były zawarte w byłym zaborze pruskim czy austriackim w formie bezwyznaniowej. Wszystkie te związki mogły być potencjalnie unieważnione przez sądy Kościoła rzymskokatolickiego z braku formy kanonicznej, a władze państwowe musiałyby te wyroki honorować. Byłaby to całkowita anarchizacja stosunków prawnych w państwie.

Ministerstwo Sprawiedliwości tuż po ogłoszeniu konstytucji marcowej opowiadało się za niczym nieskrępowanym stosowaniem prawa kanonicznego w sądach Kościoła rzymskokatolickiego. Wykładnia art. 114 konstytucji w tym okresie z pewnością nie odpowiadała zasadzie nadrzędności prawa państwowego. Wydaje się jednak, że przynajmniej w niektórych instytucjach rządowych popierano wówczas pogląd o nadrzędności prawa państwowego względem kanonicznego. Unikano jednak argumentacji opartej na postanowieniach konstytucji, co sugeruje

\footnotetext{
14 „Rocznik Ewangelicki” 1925, s. 281.
}

15 AAN, MWRiOP, 34 i nast./1345. 
brak jasności co do rzeczywistego znaczenia jej postanowień, w szczególności zaś art. 114. Ministerstwo Wyznań Religijnych i Oświecenia Publicznego forsując, w odpowiedzi na stanowisko ministra Sobolewskiego, tezę o nadrzędności państwowego prawa międzywyznaniowego, powoływało się nie na postanowienia konstytucji, lecz na art. 17 ust. Obcych Wyznań (Zb. Pr. tom XI cz.1) ${ }^{16}$.

Można zatem zaryzykować tezę, że wykładnia art. 114 ewoluowała, a ściślej rzecz biorąc ucierała się w toku ostrego konfliktu między konsystorzami ewangelickimi a Sądem Arcybiskupim Warszawskim, który miał przecież bezpośredni związek z rządzeniem się przez Kościół rzymskokatolicki swoimi prawami. Poza tym istotą tego konfliktu było dążenie do utrzymania w niepodległej Polsce, istniejącego w czasach carskich, podporządkowania sądownictwa kościelnego przepisom państwowego prawa międzywyznaniowego. Należy jednak podkreślić, że Ministerstwo Wyznań Religijnych i Oświecenia Publicznego nie prezentowało jednoznacznego stanowiska, a sprawa prawnej oceny unieważnień stała się przedmiotem swoistej rozgrywki w jego łonie. Poglądu o nadrzędności prawa państwowego broniła tylko ta jego część, która nie była związana z wydziałem kierowanym przez katolickiego biskupa A. Szelążka. Wydział ten opracował opinię dotyczą skarg ewangelickich. ${ }^{17}$ Wydział ewangelicki Departamentu Wyznań MWRiOP pominięto, przedkładając mu jedynie ex post akta sprawy do wiadomości ${ }^{18}$.

16 AAN, MWRiOP, 5 i nast., 17/1345. „O ile bowiem art. 3 punkt 3 Pr. o małż. podaje, że przypadki nieważności objęte są prawem kanonicznem i na zasadzie tego prawa w prawie niniejszym tj. ustawie wymienione, to art. 17 Ust. Obcych Wyznań (Zb. Pr. tom XI cz. 1) zacieśnia i wyjaśnia stosowanie prawa kanonicznego głosząc, że »żadne bulle, listy, wskazania i w ogóle żadne pochodzące od rządu papieskiego akty nie mogą być wykonywane w Ces. i Wielkim Ks. Fin. bez najwyższego zezwolenia J.C. Mości, wyjednywanego przez Ministra Spraw Wewnętrznych po uprzednim przekonaniu się, że akty te nie zawierają nic sprzeciwiającego się ustawom państwowym «. Prerogatywy zaś b. carskiego rządu, jak słusznie zauważa Konsystorz ER w swem piśmie z dnia 2 VI 1921 r. L 952 przeszły siłą faktu na odnośne władze polskie, w tym wypadku więc na Suwerenny Sejm Ustawodawczy, do którego kompetencji też należy zatwierdzenie rozporządzeń papieskich, względnie uzgodnienie postanowień Nowego Kodeksu Kościelnego z r. 1917 z obowiązującymi na terenie RP ustawami państwowemi”.

${ }^{17}$ AAN, MWRiOP, 31 i nast./1345. Opinia z dnia 30 IX 1921 r. podpisana przez A. Szelążka i zatytułowana: „wniosek Wydziału wyznania Katolickiego w sprawie skargi Konsystorzów Ewangelickich przeciwko Sądowi Arcybiskupiemu Warszawskiemu z powodu unieważniania małżeństw".

${ }^{18}$ AAN, MWRiOP, 5 i nast., 17/1345. W dniu 22 XI 1920 r. Ministerstwo Sprawiedliwości wystąpiło do Ministerstwa WRiOP o opinię ,w sprawie oskarżenia, jakie Konsystorz EA wytoczył przed forum Ministerstwa Sprawiedliwości przeciw Sądom Konsystorskim Katolickim, zwłaszcza Sądowi Arcybiskupiemu Warszawskiemu o unieważnianie małżeństw mieszanych, zawartych w kościele ewangelickim. Sprawę tę, lubo z natury rzeczy zainteresowane nią były dwa wyznania, oddano do zreferowania wydziałowi do spraw wyznania rzymsko-katolickiego, a opinję przez ten wydział wyrażoną przesłano Ministerstwu Sprawiedliwości, jako opinję Ministerstwa WRiOP - 
Zasadnicze znaczenie miała niewątpliwie inspiracja takiej, a nie innej wykładni prawa. Wydaje się, że roli tej nie można przypisać wyłącznie Kościołowi rzymskokatolickiemu, aczkolwiek problem ten wymaga dalszych badań źródłowych. Wątpliwa jest w tym względzie wyłączna inicjatywa A. Szelążka. Był on z pewnością zaangażowany w przeforsowanie korzystnej dla kościoła wykładni. Niemniej przebieg sprawy wskazuje, że czynniki rządowe należycie odczytały intencje Kościoła, zaś resort sprawiedliwości przyjął aktywną postawę w kreowaniu odpowiedniej interpretacji konstytucji. Fakt bowiem, że Ministerstwo Sprawiedliwości tuż po ogłoszeniu konstytucji bezceremonialnie uznało, że przepisy międzywyznaniowe dekretu z 1836 r. „nie przegradzają i nie mogłyby przegradzać drogi kościołowi katolickiemu rządzić się prawem kanonicznem, gdy sprawa o sąd jego potem się oprze", nie pozostawia najmniejszych wątpliwości co do wykładni art. 114. Ministerstwo Sprawiedliwości nie zawęziło stosowania prawa kanonicznego jedynie do zakresu wskazanego w ustawie państwowej, lecz uznało, że wychodząc z samego pojęcia prawa kanonicznego, tj. kościelnego oraz w oparciu o art. 2, 3 i 73 PM, kościół stosować może w sprawach małżeńskich tak formalne, jak i materialne prawo kanoniczne, w tym dekret Ne temere ${ }^{19}$. Okoliczność zaś, że wzmiankowane przepisy prawa małżeńskiego znajdują zastosowanie tylko wówczas, gdy zachodzi w sprawie małżeńskiej właściwość sądownictwa katolickiego umknęła ministrowi Sobolewskiemu. W piśmiennictwie ujawnił się wprawdzie pogląd, że jurysdykcję katolicką w sprawach małżeńskich ogranicza art. 113 zdanie ostatnie konstytucji, niemniej w 1921 r. negatywnie ustosunkowany do stanowiska Ministerstwa Sprawiedliwości, wydział ewangelicki Dep. Wyznań MWRiOP nie powoływał się w tym względzie ani na ten, ani na jakikolwiek inny przepis ustawy zasadniczej.

Nie można zatem z góry przesądzać, że poglądy resortu sprawiedliwości powstały tylko z inspiracji A. Szelążka. W tzw. wniosku A. Szelążka (wzmiankowana opinia z 30 IX 1921 r.) spotykamy się wprawdzie z tezami odpowiadającymi tezom znajdującym się w powyższym piśmie Ministerstwa Sprawiedliwości. Trudno jednak ostatecznie rozstrzygnąć, kto odgrywał rolę czynnika wiodącego. Generalnie przyjąć można, że koncepcja nieograniczonego stosowania prawa kanonicznego w sprawach małżeńskich wypracowana została $\mathrm{w}$ dużej mierze $\mathrm{w}$ instytucjach rządowych. Kościół oczywiście ją podchwycił, a następnie forsował. Wielce wymowna dla omawianej sprawy jest postawa Ministerstwa WRiOP. Mi-

względnie Departamentu Wyznań (a więc z domniemaniem placet Wydziału do Spraw Wyznań Ewangelickich). Post factum dopiero przedłożono Wydziałowi II-mu akta sprawy do przejrzenia, stawiając go tym sposobem wobec faktu dokonanego w tak bardzo doniosłej sprawie".

${ }_{19}$ Art. 3 PM stanowił: przypadki nieważności obięte są prawem kanonicznem, i na zasadzie tegoż prawa, w prawie ninieyszem wymienione. 
nisterstwo to bowiem unikało argumentacji opartej na postanowieniach konstytucji w celu uzasadnienia swoich racji.

Ponadto w świetle zachowanych w AAN źródeł można również odnieść wrażenie, że Dyrektor Departamentu Wyznań MWRiOP Piekarski nie przejawiał nadmiernego zaangażowania $\mathrm{w}$ tej sprawie, najprawdopodobniej ze strachu przed własnym podwładnym biskupem A. Szelążkiem. Wskazuje na to także zachowanie Piekarskiego, związane z korespondencją duchowieństwa katolickiego, kwestionującego skuteczność małżeństw zawartych w innych kościołach ${ }^{20}$. Na brak znaczenia dekretu Ne temere w stosunkach cywilnoprawnych wskazywali bowiem duchowni prawosławni. Włodzimierz, biskup Warszawskiej i Chełmskiej Eparchji w piśmie do Ministerstwa WRiOP z dnia 2 IV 1921 r. informował:

Podczas mojej ostatniej wizyty zimą było podjęte pytanie o tym, że niektórzy przedstawiciele rzymsko-katolickiego Duchowieństwa nie uznają prawnymi mięszane śluby, dokonane przez prawosławne duchowieństwo pomiędzy osobami wyznania prawosławnego a rzymsko-katolickiego. Pan Dyrektor Departamentu Wyznań zwrócił mi uwagę, że podobne czyny rzymsko-katolickiego duchowieństwa są nieprawne, ponieważ, wskutek uznanych w Polsce praw, mięszane śluby uznane prawnymi narówni ze ślubami, dokonanymi przez Duchowieństwo rzymsko-katolickie.

Dyrektor Piekarski wyparł się jednak tej wypowiedzi. Na niniejszym piśmie znajduje się bowiem podpisany przezeń, odręczny dopisek: „takiego lub podobnego oświadczenia nigdy nie wyraziłem" ${ }^{21}$. W takich oto warunkach kształtowała się wykładnia art. 114 konstytucji marcowej.

Wydaje się jednak, że w połowie 1921 r. pogląd o obowiązywaniu dekretu Ne temere na forum cywilnym nie zyskał pełnej aprobaty w sferach rządowych. Ministerstwo Wyznań Religijnych i Oświecenia Publicznego podchwyciło argumentację konsystorza kalwińskiego, odnoszącą się do postanowienia

${ }^{20}$ AAN, MWRiOP, 6/1177. W piśmie Proboszcza i Dziekana Nowogródzkiego do Starosty Nowogródzkiego z dnia 26 I 1921 r. czytamy: „Objeżdżając parafję moją stwierdziłem liczne fakty mieszanych małżeństw prawosławnych z katoliczkami i odwrotnie zawartych w ostatnich latach zawieruchy wojennej w cerkwi prawosławnej, jak również w ostatnich czasach, coraz częściej daje się stwierdzić łatwość ze strony duchownych prawosławnych błogosławienia takich małżeństw. Tymczasem na podstawie... dekretu o zaręczynach i małżeństwie... (p. III) tego rodzaju małżeństwa dla strony katolickiej w sumieniu i prawie są żadne. Wobec tego stwarza się: 1 . Sytuacja ciężka pod względem moralnym dla strony katolickiej gdyż uważaną być musi jako żyjąca bez ślubu i jako taka w kościele traktowana. 2. Sytuacja fałszywa pod względem prawnym i życiowym dla strony prawosławnej, gdy strona katolicka, idąc za nakazem kościoła i sumienia, stronę prawosławną opuści, a tembardziej, gdy będąc wolną prawnie w ponowne związki małżeńskie wstąpi. Donosząc o powyższem, uprzejmie proszę sprawę niniejszą w drodze urzędowej skierować do odpowiednich instancyj, skąd wyszłe odpowiednie zarządzenia szerzeniu się szkodliwych pod każdym względem małżeństw mieszanych zapobiegną".

${ }^{21}$ AAN, MWRiOP, 18/1177. 
art. 17 ust. Obcych Wyznań. W konsekwencji podjęte zostały działania mające na celu podważenie poglądu Sobolewskiego, że państwowe prawo międzywyznaniowe nie wiąże sądów kościelnych. Działania te w resorcie wyznań oględnie określono jako zmierzające do „sprecyzowania swego zasadniczego stanowiska w tej sprawie"22. Departamentowi Wyznań MWRiOP nie chodziło jednak o sprecyzowanie, lecz o zrewidowanie poprzedniego stanowiska, o którego kształcie zdecydował A. Szelążek. Przyjęcie aktywnej postawy przez wydział ewangelicki Departamentu Wyznań miało zatem na celu obalenie przeforsowanego przez A. Szelążka oraz Ministerstwo Sprawiedliwości stanowiska odnośnie zakresu stosowania prawa kanonicznego w sprawach małżeńskich. Niestety wywody resortu wyznań nie były w pełni zadowalające z perspektywy konstytucyjnej. Odnosiły się raczej do kwestii stosowania art. 17 ust. Obcych Wyznań w nowych warunkach prawno-politycznych po odzyskaniu niepodległości aniżeli do wykładni konstytucji. Konkluzja była jednak korzystna dla zasady nadrzędności prawa państwowego. Słusznie podniesiono, że art. 1 do 97 PM, zamieszczone w rozdziale o małżeństwie osób wyznania rzymskokatolickiego (rozdz. I), nie mogą mieć zastosowania w sprawach małżeństw mieszanych, których dotyczył rozdz. VI, ,a argumentacja, na takich wywodach oparta, trafić musi w próżnię"23. Opierając się na przytoczonych postanowieniach prawa małżeńskiego z 1836 r. wydział ewangelicki Dep. Wyznań MWRiOP uznał, iż nie ma wątpliwości, „któreby mogły posłużyć za obronę i usprawiedliwienie stanu faktycznego, stwarzanego przez ostatnie praktyki Katolickich Sądów Konsystorskich”. Takiego samego zdania był J. Glass, stwierdzając, ,że unieważnianie przez konsystorze katolickie małżeństw, zawartych przy udziale duchownych ewangelickich, jako nie oparte na żadnym przepisie prawa obowiązującego, stanowi bardzo dotkliwe i przykre w skutkach nadużycie" ${ }^{24}$.

Ministerstwo Wyznań Religijnych i Oświecenia Publicznego w ślad za konsystorzem kalwińskim wskazywało, że uprawnienia cara przeszły na odnośne władze polskie, w tym wypadku na Sejm Ustawodawczy, do którego kompetencji należy zatwierdzenie rozporządzeń papieskich, względnie uzgodnienie postanowień Nowego Kodeksu Kościelnego z r. 1917 z obowiązującymi na terenie RP ustawami państwowymi ${ }^{25}$. Uwagi te, a zwłaszcza ostatnia $z$ nich, nie były pozbawione sensu, ale jednocześnie świadczyły o przyjęciu przez resort wyznań określonego założenia w przedmiocie wykładni konstytucji. Opierało się ono na przyjęciu status quo do czasu dostosowania dawnych przepisów do postanowień

\footnotetext{
${ }^{22}$ AAN, MWRiOP, 5 i nast./1345.

${ }^{23}$ AAN, MWRiOP, 5 i nast., 17/1345.

24 „Rocznik Ewangelicki” 1925, s. 282.

${ }^{25}$ AAN, MWRiOP, 5 i nast., 17/1345.
} 
konstytucji. Co jednak miało wynikać z postanowień konstytucji w kwestii zakresu obowiązywania prawa kanonicznego? W tym kontekście podniesienie kwestii dostosowania było znamienne. Po co bowiem dostosowywać prawo cywilne do kościelnego, skoro rządzenie się przez Kościół swoimi prawami odnosi się tylko do wewnętrznej sfery stosunków kościelnych?

Podniesienie kwestii dostosowania sugeruje, że uznano prawo międzywyznaniowe za sprzeczne z prawem kanonicznym, którym Kościół miał się rządzić, a zatem nie chodziłoby o sferę wewnętrzną jego działalności. Przepisy prawa międzywyznaniowego, choć sprzeczne z prawem kanonicznym, nie mogły jednak utracić mocy obowiązującej, bowiem konstytucja marcowa w art. 126 ust. 2 przewidywała dostosowanie dawnych ustaw do postanowień konstytucji w drodze ustawodawczej. Rozumowanie zaprezentowane przez resort wyznań polegało zatem na karkołomnej obronie zasady nadrzędności prawa państwowego. Nie chodziło o to, że prawo cywilne, choć sprzeczne z prawem kanonicznym, zachowuje moc, bo rządzenie się przez Kościół rzymskokatolicki swoimi prawami, o którym mowa w art. 114, dotyczy jedynie wewnętrznych stosunków kościelnych. Argumentacja resortu wyznań zakładała coś odmiennego, mianowicie to, że prawo kanoniczne ma znaczenie w stosunkach cywilnoprawnych w myśl art. 114, ale zarazem konstytucja przewiduje w art. 126 ust. 2 dostosowanie prawa cywilnego do prawa kanonicznego w drodze ustawodawczej. Wniosek ten wydaje się logiczny, bowiem gdyby MWRiOP nie poczyniło takiego założenia, to uwaga o uprawnieniu Sejmu w przedmiocie dostosowania prawa cywilnego do prawa kanonicznego byłaby bezprzedmiotowa.

MWRiOP zmierzało do skądinąd słusznej konstatacji, że w myśl art. 126 ust. 2 dawne ustawy do czasu dostosowania zachowują moc prawną, stąd art. 192, 194 i 196 PM nadal obowiązują sądy Kościoła rzymskokatolickiego. Tym niemniej, nie trudno dostrzec, że wywód ten zakłada, że art. 114 konstytucji nie daje się pogodzić z przepisami prawa międzywyznaniowego, stąd konieczne będzie dostosowanie. Wniosek z tego płynie, że art. 114 odnosi rządzenie się przez Kościół swoimi prawami do stosunków zewnętrznych. Kwestia wykładni art. 114 odnoszącej postanowienie o rządzeniu się przez Kościół swoimi prawami do sfery wewnętrznych stosunków kościelnych w ogóle nie została podniesiona przez MWRiOP. Wydaje się, że takie stanowisko w sferach rządowych zakorzeni się dopiero w toku prac nad konkordatem.

Należy zauważyć, że pogląd o wpływie art. 114 na państwowe prawo międzywyznaniowe został zaakceptowany w orzecznictwie SN, ale wyłącznie w aspekcie przepisów dotyczących kompetencji sądownictwa prawosławnego. Wybiórcze stanowisko SN w kwestii oddziaływania art. 114 na kompetencję sądów kościelnych w sprawach małżeńskich wiązało się z uznaniem przepisów dotyczących prawosławia za antypolskie (Zb. Orz. 172/1926). 
Interesująca jest także kwestia art. 113 konstytucji, a ściślej rzecz biorąc jej brak w wywodach MWRiOP. Wyraźny nakaz przestrzegania prawa państwowego zawierał bowiem art. 113 zdanie ostatnie: „żaden związek religijny jednak nie może stawać w sprzeczności z ustawami Państwa”. Fakt, że nakaz ten nie został zamieszczony $\mathrm{w}$ art. 114, lecz w przepisie stanowiącym osobną jednostkę redakcyjną, wydatnie zaciążył na interpretacji konstytucji, powodując szereg wątpliwości co do zastosowania art. 113 względem Kościoła rzymskokatolickiego. Kościół ten skrzętnie wykorzystał zaistniały stan rzeczy. Lansowany był mianowicie pogląd, że art. 113 dotyczył wyznań uznanych, z wyjątkiem katolickiego, którego pozycję regulował wyłącznie art. 114. Wydaje się, że tego stanowiska w $1921 \mathrm{r}$. nie kwestionował nawet wydział wyznań ewangelickich w Departamencie Wyznań MWRiOP. Wydział ten uznawał wprawdzie przepisy państwowego prawa międzywyznaniowego za obowiązujące Kościół katolicki, lecz nie z racji postanowienia art. 113, na który zresztą się nie powoływał. Miarodajny w tej materii był wyłącznie przepis art. 17 Ust. Obcych wyznań.

Podsumowując, w ocenie wydziału ewangelickiego Departamentu Wyznań MWRiOP, art. 114 nie uchylał z dniem 1 VI 1921 r. przepisów państwowego prawa międzywyznaniowego względem kurii katolickich. Przepisy te pozostają w mocy do czasu wydania specjalnej ustawy dostosowawczej w myśl art. 126 ust. 2 konstytucji. Innymi słowy, konstytucja zachowywała status quo do czasu wydania wspomnianej ustawy. Było to więc wyjaśnienie wątpliwości trapiących W. Jaworskiego, który postawił pytanie, co ma się dziać do czasu ratyfikacji konkordatu w sytuacji, gdy konstytucja uznała prawo kanoniczne. Z postępowania wydziału ewangelickiego Dep. Wyznań MWRiOP nie wynika jednak, aby wydział ten przewidywał płynące z samej konstytucji ograniczenie jurysdykcji matrymonialnej sądów Kościoła rzymskokatolickiego. Można zatem odnieść wrażenie, że dopiero w późniejszym okresie zaczęto lansować tezę o ograniczeniu tej jurysdykcji przez art. 113. Niemniej w roku 1921 pogląd ten z pewnością nie okrzepł w takim stopniu, aby odgrywać istotną rolę w polemice na temat wykładni konstytucji.

Zamieszanie w sprawie wykładni art. $114 \mathrm{w}$ sferach rządowych nie było odosobnionym zjawiskiem. Przedstawiciele nauki prawa również nie mieli zadowalającego pomysłu na rozwiązanie problemu rządzenia się przez Kościół swoimi prawami. W. Komarnicki podzielał stanowisko W. Jaworskiego, że art. 114 posiada istotną lukę, bowiem nie zawiera wskaźnika, które prawo (państwowe czy kanoniczne) będzie miarodajne w razie kolizji ich przepisów do czasu ratyfikacji konkordatu $^{26}$. J. Glass uważał natomiast, że

${ }^{26}$ W. Komarnicki, Polskie Prawo..., s. 382, przypis. 
usunąć te anormalne stosunki może jedynie ustawa ratyfikacyjna, wydana w związku z układem, jaki na podstawie art. 114 ust. 2 Konstytucji ma być zawarty z Kurją Rzymską, celem oznaczenia stosunku państwa do kościoła katolickiego, ustawa, która wyjaśni, czy przewagę w Polsce posiada rzymskie prawo kanoniczne, czy na konstytucji oparte polskie ustawodawstwo sejmowe ${ }^{27}$.

Pokładane w obu aktach nadzieje okazały się jednak płonne. Najdobitniej wyraził to chyba J. Osuchowski, stwierdzając, że „brak wyraźnej korelacji pomiędzy art. I konkordatu oraz odnośnymi postanowieniami art. art. 112-114 Konstytucji marcowej jeszcze bardziej umocniło stanowisko kościoła w kwestii nieograniczonego i niezależnego od państwa charakteru jego władzy"28. Konkordat nie zawierał żadnych postanowień w przedmiocie prawa małżeńskiego. Problematykę tę pozostawiono bowiem do rozstrzygnięcia prawu państwowemu. J. Wisłocki wskazuje jednak, że taki obrót sprawy odpowiadał interesom Kościoła ${ }^{29}$.

Pewnym przełomem, przynajmniej w sferze judykatury, było kluczowe dla problematyki małżeństw mieszanych orzeczenie Kompletu Izby I SN w sprawie małżeństwa Bremerów. SN w orzeczeniu z dnia 8 XI 1926 r. w sprawie Bremerów próbował rozwiać wątpliwości dotyczące zakresu stosowania prawa kanonicznego na forum cywilnym. SN zastanawiał się nad pytaniem: „,czy przepis art. 196, jak zresztą całe Prawo o Małżeństwie z r. 1836, o ile nie jest zgodne z prawem kanonicznem, nie zostało uchylone przez art. 114 Konstytucji...” oraz przez »Konkordat...«, którego art. 1 zapewnia Kościołowi wykonywanie Jego jurysdykcji zgodnie z prawem kanonicznem, artykuł zaś XXV opiewa, iż wszystkie ustawy i dekrety sprzeczne z postanowieniami poprzednich artykułów, tracą moc prawną z chwilą wejścia w życie Konkordatu.” Interesujące jest, że po wojnie W. Kozubski sugerował sprzeczność art. 207 PM z prawem kanonicznym w sprawach związanych z przywilejem Pawłowym. Sprzeczność ta prowadzić miała do uchylenia powyższego przepisu przez art. 114 konstytucji oraz art. XXV konkor-

27 „Rocznik Ewangelicki” 1925, s. 282.

28 J. Osuchowski, Prawo wyznaniowe Rzeczpospolitej Polskiej 1918-1939, Warszawa 1967, s. 365 .

${ }^{29}$ J. Wisłocki, Konkordat 1925, s. 222, podaje, że konkordat nie rozwiał jednak wszystkich wątpliwości. „Kuria potraktowała polskie propozycje jako dogodne dla kościoła, a zresztą nie mogła już niczego więcej żądać. Sprawę uznania sakralnej formy małżeństwa odłożono do późniejszych rozmów i w świetle obowiązujących w Polsce przepisów była to dla kurii decyzja możliwa do przyjęcia. Ta właśnie forma zawierania związków małżeńskich była w Polsce powszechna, a do jej zmiany - jak się później okazało - nie dopuścił polski episkopat. $Z$ węzłowych zagadnień stosunku państwa do kościoła pozostało tylko do negocjacji uznanie religii rzymskokatolickiej za religię państwową. Negocjacje na ten temat nie były jednak możliwe, bo wymagały zmiany konstytucji, a nie były zresztą potrzebne skoro konstytucja przyznawała religii rzymskokatolickiej naczelne stanowisko w państwie. Wprawdzie to »naczelne stanowisko« miało być zachowane »wśród równouprawnionych wyznań«, ale faktyczny układ stosunków politycznych w Polsce przesądzał nadrzędny charakter kościoła katolickiego nad innymi wyznaniami”. 
datu $^{30}$. SN stwierdził jednak, że ,art. 114 nie stanowi, by Kościół Katolicki w tych dziedzinach swej działalności, które rodzą skutki prawne natury świeckiej czy to w zakresie prawa prywatnego, czy publicznego, mógł stosować własne prawa nawet wówczas, gdy stoją one w sprzeczności z ustawami Państwa”. Podobnie konkordat nie uchylał sprzecznych z nim przepisów państwowych, gdyż „uznanie jurysdykcji sądów duchownych katolickich w granicach, oznaczonych przez kanony, wobec istnienia małżeństw mieszanych byłoby równoznaczne z uznaniem prawa kanonicznego za obowiązujące dla osób innych wyznań, co oczywiście byłoby sprzeczne z jedną z naczelnych zasad Konstytucji, która uznaje równouprawnienie wyznań" (Zb. Orz. 172/1926).

SN powołuje się w tym względzie na dyskusje sejmową w sprawie ustawy o zatwierdzeniu konkordatu oraz wyjaśnienia przedstawicieli rządu poczynione na forum komisji sejmowej, że „przyznana Kościołowi Katolickiemu jurysdykcja odnosi się tylko do wiernych, t.j. do tych, którzy się tej jurysdykcji dobrowolnie poddali; powołany zaś art. XXV Konkordatu ma na myśli zniesienie tych ustaw państw zaborczych, które wyraźnie były przeciwko Kościołowi Katolickiemu wymierzone; wobec tego SN dochodzi do wniosku, iż po zawarciu i ratyfikacji Konkordatu w d. 10 lutego 1925 r. art. 196 PM wyłączający jurysdykcję sądów duchownych rzymsko-katolickich w sprawach ważności małżeństw mieszanych, zawartych w kościołach ewangelickich lub prawosławnych, nadal obowiązuje; Konkordat o tyle tylko wniósł zmianę, iż sędziowie duchowni biorący udział w wydaniu w powyższych sprawach wyroków, opartych na zasadach prawa kanonicznego, nie mogą ulegać odpowiedzialności karnej za niezachowanie przepisów prawa cywilnego..." (Zb. Orz. 172/26). Opierając się na orzeczeniu w sprawie Bremerów, Ministerstwo Sprawiedliwości zajęło jednoznaczne stanowisko w sprawie wykładni art. I konkordatu. W piśmie Ministra Meysztowicza do Prezesa Rady Ministrów z dnia 7 V 1928 r. zaznaczono, że w art. I konkordatu, „państwo zapewnia kościołowi swobodne wykonywanie jego jurysdykcji kościelnych zgodnie z prawem kanonicznem. Jurysdykcję tę, pro foro interno, wykonują sądy duchowne, jako stała instytucja kościelna niezależnie od ustawodawstwa państwowego i ukształtowania się stosunku państwa do kościoła i ograniczenia jej aktem ustawodawczym świeckim"31.

Pogląd ten był obecny w sferach rządowych i piśmiennictwie do końca istnienia II RP. Odtąd jurysdykcji cywilnej Kościoła rzymskokatolickiego nie postrzegano jako uprawnienia przysługującego sądom kościelnym, niezależnie od ustaw państwowych. Kościół mógł jedynie wykonywać jurysdykcję kościelną w sposób

${ }^{30}$ W. Kozubski, Przypadek zastosowania Privilegium Paulianum, „Ateneum Kapłańskie”, t. 50 , s. 70 i n.

${ }^{31}$ AAN, MWRiOP, 93/1345. 
przewidziany prawem kanonicznym. Niestety, stanowisko powyższe nie zyskało pełnego odzwierciedlenia w orzecznictwie SN. W niektórych sprawach zakres jurysdykcji Kościoła, wykonywanej niezależnie od ustawodawstwa polskiego, miał charakter jurysdykcji cywilnej. Chyba najbardziej rażącym przykładem takiej praktyki było orzeczenie SN z 7 X 1938 r. (Zb. Orz. 294/1939). Jego tezą przewodnią był pogląd, że art. 196 PM nie ma zastosowania w sprawach separacyjnych. Jaki zatem przepis prawa międzywyznaniowego dotyczył tych spraw? Otóż żaden. Art. 196 PM był po prostu jedynym przepisem dotyczącym właściwości sądu w sprawach małżeństw katolicko-ewangelickich. Natomiast art. 198 PM odsyłał do niego w sprawach małżeństw katolicko-sektanckich. Nie miało w tym przypadku znaczenia, czy chodzi o rozwód, czy o separację, bowiem to nie przedmiot sprawy, lecz wyznanie pozwanego decydowało o właściwości sądu. W przypadku kwestii nieważności rozstrzygało wyznanie duchownego udzielającego ślubu. Orzeczenie powyższe stwierdzało w praktyce uchylenie art. $196 \mathrm{w}$ zakresie spraw separacyjnych. Prowadziło zatem do ukształtowania się mechanizmu, według którego sąd katolicki był właściwy w każdym przypadku skierowania do niego powództwa separacyjnego, czyli niezależnie od wyznania pozwanego. Orzeczenie to stanowiło więc wyraźne odstępstwo od zasad prawa międzywyznaniowego. Uznanie wiążącego charakteru art. 196 przez SN w sprawie Bremerów, w kontekście powyższej wykładni tego artykułu, traciło względem Kościoła rzymskokatolickiego na znaczeniu. W innym z kolei orzeczeniu SN zaakceptował stanowisko papiestwa w zakresie wyłącznej właściwości specjalnego sądu w Stolicy Apostolskiej w przedmiocie niektórych spraw małżeńskich, bo rzekomo miało to wynikać z prawa małżeńskiego z $1836 \mathrm{r}$. (Zb. Orz. 222/1931). W rezultacie obywatele wyznania niekatolickiego zostali pozbawieni właściwego forum sądowego w kraju.

Nie ulega jednak wątpliwości, że ostatecznie zasada nadrzędności prawa państwowego przeważyła w praktyce sądowej i administracyjnej II Rzeczypospolitej. Spekulacje wśród przedstawicieli nauki prawa trwały jednak nadal. Wśród różnorakich koncepcji wykładni przepisów wyznaniowych pojawiały się niekiedy zaskakujące tezy. Z reguły jednak trzymano się podstawowej zasady, że akty kościelne w świetle art. 114 konstytucji i art. I konkordatu, nie wywierają skutków pro foro civili, jeżeli przepis prawa państwowego tego nie przewiduje i co do zasady w swej skuteczności są ograniczone do wewnętrznych stosunków kościelnych. Zasadę rządzenia się przez Kościół swoimi prawami odnoszono zatem li tylko do wewnętrznych kwestii kościelnych. W tym kierunku idą także wywody J. Sawickiego, który komentując oba wzmiankowane przepisy uznał, że

znaczenie pierwszego zdania ustępu drugiego art. 114 jest jasne: kościół katolicki, będąc korporacją publiczno-prawną, rządzi się własnymi prawami - posiada autonomię i samorząd. Jest to maximum tego, co państwo takiej korporacji dać może. Podkreślić przy tym należy, że kościół 
katolicki rządzi się w Polsce nie tylko aktualnie obowiązującymi normami prawa kanonicznego, ale i tymi będzie się rządził, które w przyszłości będą wydane: państwo wystawiło w ten sposób niejako dokument in blanco kościołowi katolickiemu ${ }^{32}$.

Natomiast art. I konkordatu był w ocenie tego autora swego rodzaju parafrazą art. 114 ust. 2 konstytucji i nie wnosił nic nowego, prócz bliższych określeń uprawnień Kościoła w Polsce 33 .

Komisja Kodyfikacyjna zajęła stanowisko odpowiadające tezom zamieszczonym w uzasadnieniu orzeczenia SN w sprawie małżeństwa Bremerów. Uznała mianowicie, że prawo małżeńskie należy do zakresu prawa państwowego, a nie kościelnego. Wynikać to miało z postanowień konstytucji (art. 3: Zakres ustawodawstwa państwowego obejmuje stanowienie wszelkich praw publicznych i prywatnych) oraz z samej zasady zwierzchnictwa Państwa. Natomiast art. 114 nie oznaczał bynajmniej, że prawo kanoniczne wyposażone zostało w skutki cywilne, lecz że Kościół może je stosować bez potrzeby każdorazowego uznania go przez państwo $^{34}$. Z. Sitnicki polemizując z tym poglądem stwierdza, iż art. 114

rozumiany poprostu, byłby dla wyżej wyłuszczonego rozumowania Kom. Kod. druzgocącym. Istotnie, skoro Kościół rzymsko-katolicki rządzi się własnemi prawami (oczywiście: kościelnemi) i skoro prawo tego Kościoła uznaje małżeństwo za instytucje prawa kościelnego, to musi stąd wynikać niezbicie, że prawo małżeńskie katolików nie należy do zakresu ustawodawstwa państwowego ${ }^{35}$.

Innym przykładem wykładni tego przepisu była propozycja S. Grzybowskiego, zawierająca w istocie program swego rodzaju kontroli światopoglądowej obywateli.

Bo przecież nie można odmówić - pisał Grzybowski - słuszności stanowisku Kościoła katolickiego, gdy twierdzi, że rządząc się własnemi prawami, ma też prawo wymagać od swych członków, aby stosowali się do jego nakazów, i spodziewać się od Państwa, że nie użyczy swego autorytetu na przekraczanie ich tym, którzy chcą pozostać nadal członkami tego Kościoła, lecz nie chcą stosować się do jego prawa kanonicznego w tak zasadniczej sprawie ${ }^{36}$.

W ślad za tego rodzaju poglądami szła swoista wykładnia innych przepisów konstytucji, lansowana przez niektórych kanonistów. I tak,

32 J. Sawicki, Historia stosunku kościoła do państwa, Kraków 1945, s. 90.

33 Ibidem, s. 95.

${ }^{34}$ K. Lutostański, Zasady projektu prawa małżeńskiego, Warszawa 1931, s. 26 i nast.

${ }^{35}$ Z. Sitnicki, Rzut oka na projekt prawa matżeńskiego z punktu widzenia przepisów Konstytucji i wymagań życiowych, „Głos Sądownictwa” 1932, 6, s. 360.

${ }^{36}$ S. Grzybowski, Podzielność matżeństwa jako zagadnienie kodyfikacyjne, 1935, s. 23-24. 
art. 112 konstytucji posiada wprawdzie - zdaniem W. Abrahama - to znaczenie, że państwo nie będzie używało środków przymusowych, aby skłaniać obywateli do uczestnictwa w funkcjach religijnych, pozostawiając to wyłącznie sferze kościelnej, ale stąd nie wypływa wcale, aby państwo zarazem popierało czynnie opór członków pewnej społeczności religijnej wobec obowiązków, jakie przynależność do tej społeczności nakłada na tych, którzy się do tej przynależności poczuwają, przez zapewnienie im środków, zmierzających do obejścia nakazów religijnych.

\section{Dosłowne rozumienie tego przepisu, według Autora, oznaczałoby, że bierze się}

niejako w ochronę prawną tych, którzy nie chcą wystąpić ze społeczności religijnej, do której należą, ale równocześnie nie chcą także poddać się jej nakazaniom, a więc tym samem zachęca się do szerzenia oporu w obrębie związków religijnych. Że tego rodzaju tendencyj rozkładowych konstytucja polska chyba mieć nie mogła, nie można powątpiewać37.

Oznaczałoby to, że konstytucja nakreśliła bardzo konkretny program w zakresie polityki wyznaniowej państwa, mianowicie miałoby ono stać na straży katolickich dogmatów, narzucać je niepokornym katolikom, względnie uniemożliwiać łamanie przez nich ustaw kościelnych. Zwłaszcza, że w myśl doktryny katolickiej

żaden katolik nie może starać się przed sądem świeckim o rozwód od małżeństwa kościelnego ważnie zawartego, jeżeli ono pierwej nie zostało przez właściwy sąd duchowny uznane za nieważne, i to nawet wówczas, gdyby rozwiedzeni nie mieli zamiaru wstępowania w nowe związki małżeńskie, albo gdyby przez to chcieli osiągnąć tylko jakieś korzyści materjalne. W zasadzie nie może również sędzia katolik orzec rozwodu małżeństwa kościelnego ważnie zawartego, chociażby nawet wyraźnie zaznaczył, że czyni to co do jego cywilnej strony i co do skutków prawnych czysto cywilnych, a nie co do samego węzła małżeńskiego ${ }^{38}$.

\section{Poglądom tym wychodzi na przeciw zdumiewające stanowisko prokatolickiego cywilisty R. Longchamps'a de Berier, który uważał, że}

uzyskanie rozwodu przez katolików wskutek zmiany wyznania możliwe jest jednak tylko wtedy, gdy przejdą na religję, która ma jurysdykcję duchowną. Gdyby bowiem przeszli na taką religję, która nie ma jurysdykcji duchownej albo na bezwyznaniowość, sędzia cywilny, w tym wypadku do orzekania o rozwodzie powołany, powinien odmówić rozwodu na tej podstawie, że prawo z r. 1836 uznaje małżeństwo katolików za sakrament, który przez śmierć się rozwiązuje, i obejście tej zasady przez zmianę wyznania jest działaniem in fraudem legis, zabronionem art. $6 \mathrm{KCP}^{39}$.

Problematyka małżeństw mieszanych wyznaniowo unaoczniła potrzebę wprowadzenia w całej Polsce świeckiego prawa małżeńskiego, które przede wszystkim dopuszczałoby małżeństwa cywilne zawierane w formie bezwyzna-

\footnotetext{
${ }^{37}$ W. Abraham, Zagadnienia kodyfikacji prawa matżeńskiego, PPA, LII, s. 15.

38 J. Wiślicki (w:) Matżeństwo w świetle nauki katolickiej, s. 226.

39 R. Longchamps de Berier, Matżeństwo w świetle nauki katolickiej, s. 357.
} 
niowej oraz znosiłoby jurysdykcję matrymonialną sądów kościelnych. Zresztą nawet związany z Kościołem W. Abraham uznał, że nieodzowne jest rozwiązanie tego problemu w powyższy sposób ${ }^{40}$. Niemniej art. 114 konstytucji doprowadził do poważnego zamieszania w sferach rządowych. Bezradność dostrzegalna była zwłaszcza w Ministerstwie Wyznań Religijnych i Oświecenia Publicznego, które zamiast powoływać się na konstytucję odrodzonej Polski, broniło koncepcji nadrzędności prawa państwowego powołując się na unormowania rosyjskie, które uzależniały obowiązywanie aktów kościelnych od decyzji cara. Argumentacja sprowadzała sie zatem do tego, że dekret Ne temere nie obowiązuje w Polsce, bo car swego czasu go nie zatwierdził. W praktyce więc to car przesądził o nadrzędności prawa państwowego w odrodzonej Polsce, a nie konstytucja, przewidująca bliżej nieokreśloną zasadę rządzenia się przez Kościół swoimi prawami. Oczywiście, oceniając powyższą kwestię z perspektywy historycznej, należy podzielić stanowisko Osuchowskiego, że art. 114 konstytucji oraz art. I konkordatu umożliwiał rządzenie się własnymi prawami, czyli stosowanie prawa kanonicznego jedynie w sferze wewnętrznej działalności Kościoła, natomiast w sferze zewnętrznej, tj. na forum cywilnym, jedynie $\mathrm{w}$ zakresie wyznaczonym ustawami państwowymi ${ }^{41}$. Tym niemniej w początkach niepodległości, w atmosferze ostrego konfliktu na tle obowiązywania państwowego prawa międzywyznaniowego w sprawach małżeńskich oraz dominacji biskupa A. Szelążka w resorcie wyznań, nie było ani jasności w tej kwestii ani sposobności należytego jej rozstrzygnięcia.

Wydaje się, że koncepcja nieograniczonego stosowania prawa kanonicznego w sprawach małżeńskich odpowiadała pierwotnej wykładni art. 114 konstytucji.

${ }^{40}$ W. Abraham, Zagadnienia kodyfikacji prawa matżeńskiego, s. 24-25, uznał, że postanowienia kodeksu kanonicznego ,nie dadzą się żadną miarą pogodzić się z przepisami naszej konstytucji a zwłaszcza z przyznaną w art. 111 wolnością wyznania, gdyż państwo nie mogłoby uznać tych, którzy z kościoła katolickiego wedle przepisów państwowych prawnie wystąpili jako katolików i wiązać ich przepisami kościoła katolickiego, żądając, aby w kościele katolickim zawierali związek małżeński pomimo, że wyznanie, do którego obecnie należą, inaczej tę sprawę normuje. I nie możnaby się na tem oprzeć, ze duszpasterz katolicki występuje tu równocześnie w charakterze funkcjonariusza państwowego, bo takiego samego funkcjonariusza państwowego mogą mieć oni ze względu na wyznanie, jakie przyjęli. Ale nawet o ile chodzi o zwykłe małżeństwa mięszane pomiędzy katolikami a akatolikami, mogą powstać z powodu naszej konstytucji niepokonane trudności w zastosowaniu kodeksu kanonicznego. Wątpię bowiem, czy dałaby się przeprowadzić zasada, że te małżeństwa tylko w formie katolickiej mogą być zawarte. Wprawdzie w konstytucji naszej przyznano kościołowi katolickiemu naczelne stanowisko wśród równouprawnionych wyznań, lecz takie konsekwencje wobec art. 111 szłyby zdaje się za daleko. Co najwyżej możnaby postanowić, że $\mathrm{w}$ razie podobnych małżeństw mieszanych, małżeństwo w pierwszym rzędzie w kościele katolickim winno być zawarte, trudnoby jednak było odmówić mu ważności, chociaż strony zawrą je w formie, której drugi z nupturientów podlega".

${ }^{41}$ Idem, Prawo wyznaniowe..., s. 378. 
Dopiero w późniejszym okresie, gdy w pełni zdano sobie sprawę ze skutków tego stanowiska, zaczęto wycofywać się z przyjętych założeń. Proces ten widoczny jest zwłaszcza w kontekście dalszego przebiegu konfliktu na tle stosowania prawa kanonicznego pomiędzy konsystorzami ewangelickimi a Kościołem rzymskokatolickim. Finałem było orzeczenie Kompletu Izby I SN w sprawie małżeństwa Bremerów (Zb. Orz. 172/1926), w którym stwierdzono, że art. 114 konstytucji nie uchylił art. 196 PM. Radykalnej zmianie uległa również postawa czynników rządowych, na co wskazuje pismo ministra Meysztowicza do Prezesa Rady Ministrów z dnia 7 V 1928 r. Kościół rzymskokatolicki z czasem przyjął do wiadomości to rozstrzygnięcie, lecz nie zmienił swoich poglądów. Przyjętą przez Kościół taktykę w pełni obrazują przepisy Sandomierskiego Sądu Biskupiego z 1938 r. Stwierdzono tam, że

ilekroć sąd Biskupi wzgl. Kuria orzeka w drodze sądowej czy pozasądowej o nieważności małżeństwa cywilnego lub akatolickiego w zakresie tylko kościelnym, należy z reguły wydać takie orzeczenie dopiero po przedłożeniu przez stronę ważnego wobec państwa wyroku, orzekającego rozwiązanie lub nieważność danego małżeństwa. Uprzedni wyrok cywilnie ważny nie jest jednak conditio sine qua non do orzekania przez władze kościelne nieważności jakiegoś małżeństwa, gdyby okoliczności tego wymagały. Stronie należy wszelako zwrócić uwagę, że winna postarać się o to, by jej małżeństwo zostało także wobec państwa rozwiązane, wzgl. uznane za nieważne przez powołany do tego według prawa cywilnego sąd duchowny czy państwowy. Inaczej, w zwyczajnych wypadkach, nie mogłaby w kościele katolickim zawrzeć małżeństwa, a w razie ślubu byłaby narażona na kary za bigamię ${ }^{42}$.

W tym kontekście zdumiewa postawa władz państwowych, ujawniona w piśmie Ministerstwa Sprawiedliwości z 20 VI 1933 r. Czytamy tam:

Wobec istniejącego stanu prawnego rozbieżność, wytwarzająca się pomiędzy prawem cywilnem a prawem kanonicznem Kościoła Rzymsko-Katolickiego, nie może być usunięta, jedynym hamulcem może będzie przenikające powoli do świadomości ludności zrozumienie bardzo uciążliwych niekiedy następstw (obowiązek płacenia alimentów, niejasność pochodzenia dzieci zrodzonych z zawartego na podstawie wyroku Biskupiego małżeństwa) zwracania się do niewłaściwego wg. prawa cywilnego sądu duchownego ${ }^{43}$.

Wymowa tego ustępu ujawnia przede wszystkim pozbawiony wyobraźni stosunek urzędników resortu sprawiedliwości do omawianej problematyki. Wyrażono bowiem nadzieję, że wszystkie problemy rozwiąże wzrastający stan świadomości społecznej. W tej sytuacji zbyteczne było należyte egzekwowanie ustaw państwowych, wszystkie trudności miały bowiem zniknąć z upływem czasu.

${ }^{42}$ Przepisy o postęowaniu w sprawach o nieważność matżeństwa dla Sandomierskiego Sadu Biskupiego, Sandomierz 1938, s. 72.

${ }^{43}$ AAN, MWRiOP, 212/1177. 
Z działalnością sądownictwa katolickiego związane były również innego rodzaju wątpliwości, a mianowicie kiedy można było mówić o orzeczeniu jedynie w zakresie kościelnym, a kiedy o orzeczeniu skutecznym cywilnie. W tej materii nie było zresztą zgodności w orzecznictwie SN. Nie ma tam wprawdzie mowy o cywilnoprawnej skuteczności prawa kanonicznego w każdej sprawie małżeńskiej, lecz z niektórych wywodów SN można taki wniosek wysnuć. Charakterystyczne było zwłaszcza uznanie papieskiej wykładni kodeksu kanonicznego za miarodajną odnośnie właściwości specjalnego sądu kościelnego w Rzymie w sprawie małżeństwa mieszanego (Zb. Orz. 222/1931). Podobne rezultaty uzyskiwano za pomocą odpowiedniej wykładni państwowego prawa międzywyznaniowego. Była to metoda pośrednia. Nie było tu żadnych odniesień do prawa kościelnego, aczkolwiek prawo państwowe podlegało takim zabiegom interpretacyjnym, aby de facto wykluczyć jego zastosowanie w sprawie, a w konsekwencji uzasadnić właściwość sądownictwa katolickiego. Sztandarowym przykładem tej metody była koncepcja niestosowania art. 196 PM w sprawach separacyjnych (Zb. Orz. 294/1939).

\section{THE ISSUE OF INTERPRETATION OF ARTICLE 114 OF THE MARCH CONSTITUTION IN LIGHT OF THE ECCLESIASTICAL JUDICATURE IN MARRIAGE CASES}

\section{Summary}

The paper deals with the issue of interpretation of article 114 of the March Constitution from 1921 and how it shaped itself in light of the ecclesiastical judicature in marriage cases. The interpretation, which was taking shape in the ecclesiastical judicature, was connected with the implementation of domestic international law. Its provisions were mandatory in character for ecclesiastical courts. Consequently, it pertained to judicial decisions in cases concerning interfaith marriages. The key issue in this matter was the jurisdiction in marriage cases. This issue was simultaneously connected with the problem of admissibility of a divorce of an interfaith marriage. The problem was a sensitive one in character and it led to denominational conflicts which had to be resolved by the state. The Polish state was reborn in 1918 and it remained under the influence of the Catholic clergy. This factor advocated for one of the established denominations in Poland. A separate issue was the position of the Catholic denomination in light of the contemporarily binding law. This was a contentious issue after Poland regained its independence. Article 114 of the Constitution from 1921 regulated this problem in a manner which raised doubts. However, one can determine the practical dimension of the key provision of article 114 of the March Constitution on the basis of ecclesiastical judicial decisions. According to the provision, the Catholic denomination abided by its own rules. The influence of this provision on the practise of domestic international law by ecclesiastical courts emerges simultaneously from these judicial decisions. 
LE PROBLEME DE L'INTERPRETATION DE L'ARTICLE 114 DE LA CONSTITUTION DE MARS A LA LUMIERE DE LA JURISPRUDENCE DE L'ÉGLISE EN MATIERE MATRIMONIALE

\section{Résumé}

L'article traite des problèmes liés à l'interprétation de l'art. 114 de la Constitution de mars de 1921, élaborée à la lumière de la jurisprudence de l'Église en matière matrimoniale. L'interprétation qui s'est développée dans la jurisprudence de l'Église était liée à l'application du droit étatique interconfessionnel, qui était absolument obligatoire pour les tribunaux ecclésiastiques. Par conséquent, elle concernait la jurisprudence en matière de mariage interconfessionnel. Dans une situation pareille, la question clé était la compétence du tribunal en matière matrimoniale. Cette question était en même temps liée au problème de l'acceptabilité du divorce comme rupture officielle d'un mariage religieux. Ce problème était de nature sensible et entraînait des conflits religieux que l'État devait résoudre.

Après sa restauration en 1918, l'État polonais restait sous l'influence du clergé catholique. Ainsi, le facteur factuel faisait appel à l'une des confessions reconnues en Pologne. La position de la religion catholique à la lumière du droit applicable était une question distincte. Après avoir retrouvé l'indépendance du pays, cette question s'est posée discutable. L'article 114 de la Constitution de 1921 régissait cette question d'une manière qui soulevait des doutes. Cependant, il est possible de déterminer l'application pratique de la disposition clé de l'art. 114 de la Constitution de mars, selon lequel la religion catholique était régie par ses propres lois. Cette jurisprudence révèle en même temps l'impact de cette disposition sur l'application du droit étatique interreligieux par les tribunaux ecclésiastiques. 